\section{Mozaikok a kommunikáció kultúrtörténetének női dimenzióján}

A nöi kommunikáció kultúrtörténete. Tanulmányok. Szerk. Sipos Balázs - KRász Lilla. Budapest, Napvilág Kiadó, 2019. 202 oldal.

A nőtörténeti kutatások az elmúlt évtizedekben egyre nagyobb lendülettel, egyre több tudományterület felé nyitva tárják fel az elmúlt korok női dimenzióit, melynek módszertana és vizsgált forrásanyagtípusa is széles spektrumot ölel fel. A problématörténeti csomópontok köré szerveződő kutatások a magánszféra hagyatékait éppúgy vizsgálják, mint a korábbi évszázadok szintetizáló munkáit. A nőtudományok nyitottságát jól mintázza, hogy ezen csomópontok kevéssé határolhatók le egy-egy tudományterület sajátjaként. Az inter- és multidiszciplinaritás különféle témákra koncentráltan kristályosodik ki, legyen az nevelés-, művelődés-, politika-, társadalom- vagy épp olvasástörténeti. A Sipos Balázs és Krász Lilla szerkesztésében megjelent A nöi kommunikáció kultúrtörténete címủ tanulmánykötet e sorba csatlakozva a még újdonságnak számító kommunikációtörténeti megközelítést emeli a kutatás szervező témájává. Minthogy minden tanulmány történeti forrásokat vizsgál, $s$ a kommunikáció és műveltség fogalmának megjelenése gyakorta párhuzamos, vitathatatlanul fontos szerep hárul az adott korszak műveltségeszményére és a (nő)nevelés korabeli viszonyaira. A tanulmánykötet négy fejezetben, többnyire egy-egy téma (és részben hasonló forrástípus) köré specializáltan, kronologikus szálra füzve tárgyalja a női kommunikáció kultúrtörténetével kapcsolatos legfrissebb kutatási eredményeket, a magánszféra személyközi kommunikációtörténetétől a tömegkommunikációig, zömében a történeti Magyarország határain belül mozogva.

Az előszó - talán a megszokottól némileg eltérően - a szerkesztői gondolatok, illetve az ELTE BTK Történeti Intézete és Néprajzi Intézete munkatársainak kezdeményezésére létrehozott Nőtörténeti Kutatóközpont tevékenységének bemutatása mellett egy tanulmányt is közöl. A kötet egyik szerkesztője, Krász Lilla $A$ nőtörténet és a kommunikációtörténet historiográfiai perspektiváiról című írásában körültekintően és részletesen alapozza meg a kötetben foglalt tanulmányok elméleti, tudományos relevanciáját, különös figyelmet fordítva arra a már említett multidiszciplinaritásra, mely a (női) kommunikációtörténetet nem engedi - többek között - a nő-, a társadalom-, a művelödés-, a nevelés-, a politika- és az olvasástörténeti kutatásoktól elvonatkoztatva szemlélni. A historiográfiai elemzés előrevetíti a kötet tanulmányainak tudományos sokszínűségét, melyet a kiadvány további három tematikus egysége vissza is tükröz az olvasó számára. Mindemellett bőséges irodalmat is közöl az egyes tématerületek további tanulmányozásához.

Az első, több tanulmányt is felvonultató tematikus fejezet a Családi kommunikáció, levelezés kérdéskörét járja körül. A négy tanulmány közül három a 16-17. század, míg egy a 19-20. század fordulójának magyarországi levelezéseibe enged betekintést.

Lengyel Tünde kutatása $A$ kora újkori nöi müveltség problémái - elvárások, határok és lehetôségek címmel a nőnevelés irányából, Czobor Erzsébet életútjára vonatkoztatva vázolja a (családi) levél mint nevelés- és kommunikációtörténeti forrás jelentőségét. A szerző nem csupán a leányok, hanem a fiúk neveltetésének rövid bemutatására is figyelmet fordít. Mint írásából kiderül, ennek különös relevanciája, hogy míg például Esterházy Miklós vagy épp a már említett 
Czobor Erzsébet fiainak neveltetéséről és taníttatásáról részletes ismereteket szerezhetünk a levelek nyomán, addig a lányok esetében ezen feljegyzések hiányosak vagy meg sem jelennek. Visszatérö téma ugyanakkor a gyermekek egészségi állapota, illetve Czobor Erzsébet férje, Thurzó György halála utáni, a birtok körüli teendőkkel kapcsolatos levelezése.

Egy másik, szintén a korszakban élt asszony, Fugger Mária életére füzve nyújt betekintést a korszak személyközi kommunikációjába Fundárková Anna Fugger Mária, a "györi hös", Pálffy Miklós felesége és özvegye című tanulmányában. A szerző kutatásaiból kiderül, hogy Fugger Mária már menyasszonyként levelezett Pálffy Miklóssal. Fugger Mária bajor származására tekintettel a kutatónő a leveleket nyelvi szempontból is vizsgálta. Eszerint a házastársak zömében német nyelven kommunikáltak, noha leveleikben gyakorta magyar szavak is felfedezhetők. A levelezések érdekességét alkotják továbbá az özvegyi lét során kelt írások, melyet a "györi hös" özvegye sógorával, Illésházy Istvánnal folytatott. A haláláig önálló Fugger Mária a kapcsolattartás során (mely gyakorta kockázatos volt mindkét fél számára) sajátította el a birtokgazdálkodás, számadás fortélyait, így a levelezés egyfajta tanulási/tanítási módszerként is értelmezhetö.

A művelt nő 16-17. századi eszményképéról értekezik a Nöi családi szerepek: menyasszony, feleség, anya. A nöi kommunikáció szinterei a nemesi családokban címü tanulmányának bevezetőjében Duchoňová Diana, mely elsősorban az írni-olvasni tudás készségétől függött. A szerző rávilágít, hogy a levelezés bensőséges viszonyt alakított ki a levelezőpartnerek között, természetesen abban az esetben, ha nem hivatalos levelekről volt szó. Az ilyen témák tollbamondását az íródeákokhoz intézték. A személyesebb hangvételü levelek vizsgálatát a kutatónő Nyáry Krisztina levélhagyatéka nyomán, a címzettek alapján három kategóriába sorolva prezentálja: Nyáry Krisztina és Czobor Erzsébet (meny és anyós); Nyáry Krisztina és Esterházy Miklós (feleség és férj); Nyáry Krisztina és Thurzó Erzsébet (anya és leány) közötti levelezések. A nők közötti levélváltások sokszínűségét példázza, hogy Nyáry Krisztina anyósával folytatott levelezése során a szerző további három fázist különít el, illetve szemlélteti, hogy a nők közötti kommunikáció során sokkalta jellemzőbb volt a fiatalabb nők felé irányuló befolyásolási szándék (akár pozitív, akár negatív konnotációban).

A fejezet záró tanulmánya Géra Eleonóra Családi levelek, családi játszmák címü írása, mely a nemrégiben levéltárba került Rédly-Hellebranth rokonság nőtagjainak családi levelezését vizsgálja. A szerző három rövidebb egységben, s ezzel a levelek nyomán kirajzolódó életutak mentén építette fel a tanulmányt: Ilona (Rédlyné) története, Rédly Baby jövője, Berta (Hellebranthné) és gyermekei új élete Amerikában. A vizsgált életutak által kikristályosodik a 19-20. századi társadalom hagyományos és új szellemiségének találkozása. Hiszen míg Berta és Ilonka hagyományos, 19. századi leányneveltetésben részesültek, a századforduló társadalmi változásai más-más irányba (és földrészre) terelték életüket. A kutató szerint e korántsem egyedi jelenség értelmezési lehetőségeit színesítik az - inkább beszélgetésként ható - levélváltások, $s$ az ebben résztvevők különféle perspektívái.

Az első egységben megjelenő kutatások tehát a magánszférában kelt levelezések vizsgálatával térképezik fel a személyközi kommunikációt, a családtagok közötti viszonyokat, a nők lehetőségeit. A 16-17. századi női műveltség elsősorban az írni-olvasni tudásban értelmezhető, melyet nélkü- 
lözhetetlennek tartottak a (fö)nemesi családokban. Ennek elsajátításában gyakorta a férj segítette hitvesét.

A kiadvány második fejezete a Társadalmi kommunikáció és a nöiesség jelentésének formálása tematikájába illeszthető kutatásokat közli, mely primer forrásait tekintve már a nyilvános szférában történő kommunikációs műfajok tükrében szemléli a nőiesség és a társadalmi kommunikáció párhuzamát.

A 19. században kicsúcsosodó nőkérdést mutatja be Mátay Mónika Deviánsak vagy lázadók? A nöiesség diszkurziv olvasatai címü tanulmányában. A szerző széles spektrumon elemzi az 1800-as évek nőiességfogalmát. Noha a korszellemet, a nemzeti ébredést vázolja, a honleányi szerepről nem szól. Sokkal inkább az ezzel az eszményképpel kevéssé összeegyeztetheto” „nőtípusokat" helyezi fókuszba. Eképp a lionkodó („ficsúrkodó”) antiasszonyokról szóló fejezetben a női dandyzmus, az arszlánság, a fashionable hölgy ismérveit részletezi. E gondolatmenetet tovább erősíti, hogy a tanulmány második felében két konkrét életúttal, az előkelő társadalmi szerepéből kilépő Batthyány Apraxin Júliával és a nemi korlátokat is áthágó Vay Sándorral/Saroltával szemlélteti a korszak nőeszmény(kép)ét megszego" „határsértőket”.

Noha időben kevéssé ugrunk nagyot Varga Zsuzsanna tanulmányával, a technikai és politikai vívmányoknak betudhatóan a Falusi nök a propaganda célkeresztjében az 1950-es évek elején címü írásban a nők már mint a politikai propaganda céljai jelennek meg. A magánszférából itt már egyértelműen a tömegkommunikáció színterére lépünk. A nők agitációjának formája elsősorban a filmhíradóban és a sajtóban teljesedik ki, s noha a nő mint "politikai eszköz” már a korábbi történelmi korokban sem volt ismeretlen, a szerző a politikai és gazdasá- gi célok mellett rávilágít arra a tényezőre, hogy a kommunista propaganda - névleg legalábbis - egyenrangú félként tekintett a nőkre. A kutatás nem tartalmazza a propaganda hatásvizsgálati feltárását, de ez nem is kifejezett célja, jóval inkább fókuszál a nőkhöz szóló, nőkkel való tömegkommunikációs stratégiák feltárására, szemléltetésére.

Részben erre, részben pedig a korszak normarendszerének társadalmi kommunikációjára reflektál Bartha Eszter Munkásnö-interjúk és munkáséletmód-kutatások az 1970-es évek Magyarországán címü fejezetzáró tanulmánya. A szerző korabeli interjúkat vizsgál, ami önmagában is érdekes vállalkozás, hiszen - mint jelzi - nem csupán az 1970-es években készült beszélgetéseket, hanem az azokat készítő szociológusok (öszszegző) megjegyzéseit is vizsgálat alá vonta az anonimitás igényével. A szerző megjegyzi a korabeli interjúelemzések genderspecifikusságának hiányát, mely a későbbiekben további kutatásra enged teret, hiszen az 1970-es évek kutatói ezt a szempontot (a társadalmi nemek tudományának újszerủ és részben ismeretlen volta okán) még nem ve(he)tték figyelembe. Emellett feltárja, hogy a női kommunikációban az interjúk során mennyiben jelenik meg a korabeli társadalom normarendszeréhez való igazodás, s elörevetíti a téma oral history forrásokkal való bővítési lehetőségeit.

E fejezet elsősorban a nők társadalmi reprezentációját, a nőiség fogalmát és az erről (már a nyilvános szférában) folyó kommunikációval kapcsolatos kutatásokat tartalmazza. Végigkövethetjük a századforduló társadalmának viszonyulását a „határsértő” nőkhöz, majd a századközepi propaganda nők számára előirányzott célkitűzéseit, $s$ az ebben szocializált, e sémák mentén kommunikált nőkre szabott normarendszereknek az egyéni sorsokra nehezedő súlyát. 
A Társadalmi kommunikáció és nöi aktorok: tartalom-elöállitás címet viselő záró fejezet öt kutatást prezentál, melyek primer forrásokként a sajtó, az irodalom és egyéb művészeti alkotások/életutak értelmezését és elemzését alkalmazzák.

A kiadvány korábbi publikációitól eltérően időben sokkal nagyobbat lép vissza Németh György Szapphón túl. Görög költöonők, festönök és filozófusnök címü írása, mely az ókori művészettörténeti és filozófiatörténeti diszciplínák felől közelít a női kommunikációhoz. A tanulmányban festőnők, filozófusnők és költőnők élete is megjelenik hosszabb-rövidebb terjedelemben, ez utóbbiak közül pedig számos személyt is bemutat, ami összhangban áll a szerző azon megállapításával, miszerint a napjainkig ismert művelt ókori nők közül legtöbben költőnők és orvosnők voltak. Kiemeli ugyanakkor, hogy a vizuális kommunikáció terén a nők - ha arányukat tekintve csekélyebb számban is - legalább annyira tehetségesek voltak, mint férfi társaik. Továbbá - részben a korábban érintett műveltségeszménnyel, részben a nőiesség mibenlétével összhangban - Hüpatia történetével prezentálja, hogy az ókorban sem volt általános, illetve társadalmilag elismert a nők tudománnyal való foglalatossága. A filozófusnő halála hosszú időre meghatározta a nők filozófia területén való jelenlétét.

$\mathrm{Az}$ 1600-as évek könyvkiadásának anyagi és társadalmi jelentősége kerül a női kommunikációtörténet vertikumába Pesti Brigitta Nók szerepe és jelentösége a 17. századi könyvkiadás mecenatúrájában címü kutatása nyomán. A szerző kiemeli, hogy különösen a reformációt követően - a női mecenatúra megerősödött. Tanulmányában megemlíti a korszak legismertebb női mecénásait, akik nem csupán a könyvkiadásban, hanem hatalmas magángyüjtemények létrehozásában is élen jártak. A mecenatúra újdonságként fellépő tényezője ugyanakkor már nemcsak ez, hanem a könyvek elején található ajánló szövegekben a női mecénások feltűnése. Főként a reformáció és katolikus megújulás időszakában növekedett meg a magyar nyelvủ kegyességi irodalom iránti igény. Az imádságos könyvek megrendelői és támogatói között a fónemesi sorból származó hölgyek mellett a szerényebb társadalmi körök asszonyai is feltűnnek (sok esetben többen támogatva egy-egy kiadvány megjelenését).

A 19-20. század fordulóján a (tömeg) kommunikáció mint érdekérvényesítési lehetőség jelentőségét prezentálja Deáky Zita Az okleveles bábák érdekérvényesitó fórumainak kialakulása (1893-1914) címủ tanulmánya. A hazánkban második, szakmai alapon működő szervezet már a 19. század második felében szaklapot indított. A lap a szakmai kommunikáció kiaknázásban és a bábaképzés professzionalizációjában játszott hatalmas szerepet, $s$ - ahogy a szerző bemutatásában látható - a bábaság érdekérvényesítése, a sztereotípiák lebontása, az identitásképzés és a szakmai fórum megteremtése is célja volt. Az önszerveződés e formáját a felélénkülő lapkiadás, a 20. században egyre nagyobb hangot kapó feminista törekvések is lehetővé tették, példázva az elsősorban női szakma, a bábaság tekintélye kivívásának új fórumát, a nyilvános szférát.

Deáky Zita kutatásának szálát folytatva, a tömegsajtó megjelenésének jelentőségét és magyarországi viszonyait taglalja Sipos Balázs Hogyan lett az újságirás nöi hivatás is Magyarországon? című tanulmánya. Mint a szerző emlékeztet, női szerkesztők és írók már a korábbi évtizedekben is jelen voltak hazánkban. Ez összecseng Fábri Anna női írással kapcsolatos kutatásaival, miszerint a 19. század végére az írással foglalkozó nők kisebb része a szépirodalom terén alkotott, nagyobb hányada a „női 
ügyek” (leánynevelés, női jogok és lehetőségek szélesítése) mellett érvelve tette közzé írásait. Ugyanakkor, mint ahogy Sipos Balázs közli, ezeket az „írogató” nőket inkább aktivistaként, mintsem hivatásos újságíróként tartották számon. Vagyis a populáris sajtó megjelenése csupán a férfi szerzők professzionalizációját vonzotta magával. $\mathrm{Az}$ első hivatásos újságírónő szerepére többen is pályáznak: Zempléni P. Gyuláné Elek Irma, Szederkényi Anna, Stephani Elza, Kovács Lydia és Hollós Lipótné de Grobois Nandine is nagyjából ugyanabban az időszakban lépett az újságírói hivatás útjára.

Szilágyi Ágnes Judit írása, a Nöi müvészek és gondolkodók a Revista Atlântida (1915-1920) cimü portugál-brazil folyóiratban, egyfajta egzotikum, nemcsak a téma nemzetközisége, hanem a női kommunikáció formáinak nyomán is. A szerző sajtóelemzésében a címben jelzett Revista Atlântida címü folyóirat női tartalmait vizsgálta, felhívva a figyelmet, hogy Brazíliában a 20. század elején az analfabetizmus kiugróan magas (70-80\% körüli) arányokat mutatott a férfiak és nők tekintetében egyaránt (a nők körében magasabb volt). A művészeti lap fennállásának öt éve alatt 700 cikk jelent meg, melyek közül 15-20 tartalmazott nőktől vagy nőkről szóló írásokat. A lap arculatának része volt az irodalom és más művészeti ágak prezentálása, így a folyóirat lapjain az olvasó Virgínia Vitorino költőnő verseivel csakúgy találkozhatott, mint Helena Roque Gameiro festőnő vagy Marie-Antoinette Aussenac zongoramüvésznő méltatásával. Az Atlântida hasábjain tette közzé írásait a női egyenjogúság szószólója, Isadora Duncan, és publikálta női hivatásról szóló írását Gina Lombroso Ferrero pszichológus is.
A tanulmánykötet utolsó egysége tehát a személyközi kommunikáció és a nyilvános szféra, a tömegkommunikáció színterei után a nőt mint a nyilvános szférába lépő, produktumot előállító, szélesebb társadalmi köröket megszólító (feléjük kommunikáló) szereplőt mutatja be.

A nöi kommunikáció kultúrtörténete mind forrásanyagát, mind kutatási eredményeit tekintve széles spektrumot felölelő inter- és multidiszciplináris igénnyel válogatott tanulmányokat foglal magába, mely érzékletes és átfogó képet kíván nyújtani a kommunikáció kultúrtörténeti kutatásának magyarországi helyzetéről. Felépítésében, szerkezetében a kötet a magánszféra személyes müfajaitól, a személyközi kommunikációtól halad a nyilvános szféra, a tömegkommunikációs színterek irányába. Hiányként mutatkozik, hogy a kutatások sorából az ókort követően a 16-17. századig nem közöl ismereteket, ami - csakúgy, mint az egyes kutatások továbbgondolási lehetőségei, felmerülő kutatási kérdései szintén szükségessé és indokolttá teszi a további vizsgálatokat, forrásanyagok feltárását és feldolgozását. A szerkesztői és szerzői munka érdeme a folyamatos, fejezeteken belüli és azok közötti reflexió, a tanulmányok gondos egymás után szerkesztettsége, mely egymásba gördülő, egymáshoz szorosan kapcsolódó színes mozaikként áll össze - a szerkesztői szándékoknak megfelelően - nőtörténeti, kommunikációtörténeti olvasókönyvvé. 